\title{
ECOLOGICAL DIVERSITY OF SPINY BROOM (CALICOTOME VILLOSA (POIR.) LINK) AND SWEET BROOM (GENISTA $\times$ SPACHIANA) OF THREE DIFFERENT PROVENANCES: CHEMICAL COMPOSITION, SECONDARY COMPOUNDS OF SHRUB LEAVES AND RESPONSES TO DROUGHT STRESS
}

\author{
Mechergui, K. $.^{*}-$ SAleh Altamimi, A. ${ }^{2}-$ NAghmouchi, S. ${ }^{1}-$ JAOUAdI, W. ${ }^{1,3}$ \\ ${ }^{I}$ National Institute of Research in Rural Engineering, Waters and Forests, Carthage University, \\ B.P. 10, Hédi Karray Street, Menzeh IV, Ariana 2080, Tunisia \\ (e-mail: den_souheila@yahoo.fr) \\ ${ }^{2}$ Biology Department, College of Science, Princess Norah Bint Abdulrahman University, \\ Riyadh, Saudi Arabia \\ (e-mail: amal.alfawaz@gmail.com) \\ ${ }^{3}$ Silvo-Pastoral Institute of Tabarka, Jendouba University, B.P. 328, Tabarka 8110, Tunisia \\ (e-mail: jaouadiwahbi@gmail.com) \\ *Corresponding author \\ e-mail: mecherguikaouther2015@gmail.com \\ (Received 30 $0^{\text {th }}$ Mar 2021; accepted $19^{\text {th }}$ Jul 2021)
}

\begin{abstract}
In the first stage, levels of primary and secondary compounds, nutritive value of foliage from two fodder shrubs spiny broom (Calicotome villosa) and sweet broom (Genista spachiana) growing spontaneously in central and northern Tunisia were evaluated in order to study the ecology of species in the country. Feed components were determined by proximate analysis, while phenolic and tannin compounds were also analyzed. The foliage of $C$. villosa and G. spachiana is rich in protein (between 36 and $51 \%$ ). These two species present good protein values and acceptable levels of secondary compounds that may make a choice forage for ruminants, especially during the lean season. In the second stage the study was to examine the germination characteristics of $C$. villosa and G. spachiana under controlled conditions with different levels of salt and water stress. Seeds were sown in $\mathrm{NaCl}$ solution at different concentrations: $0,3,6,9,12$ and $15 \mathrm{~g} / \mathrm{l}$. The water-stress treatments used were $0,-0.03,-0.1,-0.7,-1$ and 1.6 MPa obtained by adding $\mathrm{PEG}_{6000}$. C. villosa and G. spachiana can withstand salinity up to $15 \mathrm{~g} / \mathrm{l}$ of salt $(31 \%$ at $37 \%$ germination at $15 \mathrm{~g} / \mathrm{l})$ and also tolerate higher levels of $\mathrm{PEG}_{6000}(30 \%-40 \%$ germination at $-1.6 \mathrm{MPa}$ ).
\end{abstract}

Keywords: environments, nutritional value, germination, drought, salinity

\section{Introduction}

The Fabaceae family (e. g. Legumes) is the most important family among dicotyledons. It contains the largest number of species useful to humans, whether food, industrial or medicinal. According to Judd et al. (2002), fabaceae species are generally herbaceous, shrubs, trees or climbing plants. The leaves are generally alternating, composed of pinnate leaves. Many species of Fabaceae have therapeutic properties and are used in traditional medicine (Calicotome villosa and Genista spachiana). Calicotome villosa (Poir.) Link subsp intermedia belongs to the Fabaceae family. This species is a thorny shrub that can grow up to $2 \mathrm{~m}$ tall (Boughalleb et al., 2019). The woody perennials particularly the rangeland shrubs as main source of sustenance and ecological significance. There is urgent need for sustainable utilization 
of shrub diversity through scientific conservation as well as the management (Rathore et al., 2011). Fabaceous species are rich in flavonoids with a percentage of $(24.24 \%)$ and the Genista genus is the richest. In general, the aerial parts contain a higher content of flavonoids. Alkaloids are present to a considerable degree in Fabaceae with a percentage of $(18.18 \%)$ and the Genista genus is the richest. The aerial parts of Fabaceae species are more widely used and richer in bioactive substances (Berrabah and Chemissa, 2017). The economic importance of these species is significant. Indeed, spiny broom (Calicotome villosa) and sweet broom (Genista spachiana) are important food and fodder plants and drugs used in therapy. In Tunisia, C. Villosa is of great interest for the rehabilitation of degraded ecosystems, food for goats and camelids, and for the use of its essential oils in phytotherapy. Indeed, recent findings revealed. that the index of livestock acceptability for C. Villosa is considered as palatable (Gamoun et al., 2018). The ethnobotanical study of the Fabaceae family shows that the latter occupies an important place in traditional medicine because of its therapeutic indications. C. villosa leaves are the richest in protein: 33.70\% (Berrabah and Chemissa, 2017). C. villosa have led to the isolation and identification of flavone glucosides, alkaloids, and anthraquinones from the leaves and flowers (Pistelli et al., 2003) flavone glucosides, steroids, and chalcone from the stems (Alhage et al., 2018), flavonols and alkaloids from the seeds (Elkhamlichi et al., 2017) and C. villosa is a source of natural antioxidants with high industrial value and could be used as a potential food source (Boughalleb et al., 2019). Calicotome villosa and Genista spachiana are classified as vulnerable in Tunisia and they are of great interest for the rehabilitation of degraded ecosystems, food for goats and camelids, and for the use of its essential oils in phytotherapy (Mechergui et al., 2017). These authors found that the tolerance of the two species to salinity and water stress allows them to bea source of food for goats and camelids during drought (Mechergui et al., 2017). The two species Calicotome villosa and Genista spachiana can be used as pasture for animals: grass, fruit, tree and shrub leaves. Moreover, the use of these fodder trees and shrubs is an old practice well known to livestock producers. This type of fodder is an important and often indispensable part of livestock feed in developing countries. Tunisia has a significant fodder deficit due to the degradation of the grazing lands. To address this deficit, the planting of forage shrubs is a renewable resource that can provide regular standing biomass throughout the year, as it can be. Tunisia is a north African country and climatically is divided into north and south parts. Southern part of the country is covered by the desert and is accounting for three quarters of the country. One of the promising options for restoration of degraded regions in southern Tunisia is to use native shrub and tree species that have multiple functions in the ecosystem. Several species of the legume family (Fabaceae) are of a high interest due to their adaptation to arid and semi-arid environments, nitrogen fixing capacity and ability to grow in poor soils (Ibanez and Passera, 1997). In the first stage, the approach in this study is to improve the quality of the basic ration by selecting the most nutritious shrub species that can be planted, since the low nutritional value of the available forage is one of the main factors limiting animal productivity. In order to make optimal use of the nutritional potential of this natural vegetation, it is necessary to know its chemical composition, the purpose of this study, which dry matter to determine the primary and secondary components and examine the hemolytic power of saponins in the leaves of nine forage shrubs, in order to improve ruminant breeding, which is a real development issue. 
In the second stage, successful establishment of plants largely depends on successful germination. Seed germination behavior in relation to thermal and salt stress is a very important determinant of the colonization capacity of a species (Ungar, 1995). Tolerance to salinity during germination is critical for the establishment of plants growing in saline soil of arid regions (Khan and Gulzar, 2003; Ungar, 1995). Increased salinity leads to a reduction and/or delay in germination of seeds of both halophytes and glycophytes. Failure of germination in saline soils often is a result of high salt concentrations of salts in the seed-planting zone. Seed germination under saline conditions occurs after high precipitation and rain apports (Khan and Ungar, 1996; ElKeblawy, 2004; Huang et al., 2003; Redondo et al., 2004). The detrimental effect of salinity and osmotic stress are generally less severe at optimum germination temperature (Gorai and Neffati, 2007; Tlig et al., 2008; Gorai et al., 2009; Maraghni et al., 2010).

The present study was undertaken to understand the fodder quality of Calicotome villosa and Gesinta spachiana leaves and the seed germination requirements of different provenances of these two species under salt and water stresses.

In this study, we wanted to answer the following specific questions: (i) nutritional value of spiny broom (Calicotome villosa) and sweet broom (Genista spachiana) for livestock; (ii) seed germination of spiny broom and sweet broom under different levels of NaCl-salinity and osmotic stress induced by polyethylene glycol ( $\left.\mathrm{PEG}_{6000}\right)$; and (iii) how do the osmotic levels of $\mathrm{NaCl}$ and $\mathrm{PEG}_{6000}$ induced water stress of the seed's environment affect seed germination?

A detailed knowledge of germination responses may provide: new insights into factors controlling plant recruitment and survival in drought-prone regions and with such adaptation strategies, these species be used to rehabilitate degraded and very stress full areas and constitutes a valuable solution to the lack of animal feed especially in dry rangelands due to the nutritional value.

\section{Materials and methods}

\section{Fodder quality of Calicotome villosa and Gesinta Spachiana leaves}

Samples were collected in spring of 2018 (May) from Meknassi which is located in center of Tunisia, Bouhedma national park which is located in south of Tunisia (Fig. 1) and of the Cap Bon forest, which is located in northeast of Tunisia. The locations and characteristics of sampled sites are (Fig. 2; Table 1). The choice of this site is motivated by the biodiversity of the floral procession and the fairly high pastoral pressure encountered there. Leaf samples of each of the two species were collected from the shrubs during spring season of the year. Leaf samples were taken from 10 shrubs per species, the latter being about $200 \mathrm{~m}$ apart from each other. On average, a sample of one kilogram of leaves per species was dried for $48 \mathrm{~h}$ in a ventilated oven set at $50{ }^{\circ} \mathrm{C}$. This temperature prevents the denaturation of the plant's chemical compounds (Makkar and Singh, 1991). The experiments were conducted using three replicates.

\section{Chemical composition of shrub leaves}

All samples of the plant material collected were analysed for dry matter (DM) and mineral matter (MM) contents according to AOAC (1990) procedures. The total nitrogenous material was determined by the Kjeldahl method (ISO 1997). The parietal 
constituents (neutral detergent, NDF - cellulose with neutral detergent; acid detergent, ADF-lignocellulose; and acid detergent lignin, ADL-lignin) were determined according to the method of Van Soest et al. (1991), while the crude fibre was determined by the Weende method (1967). The experiments were conducted using three replicates.

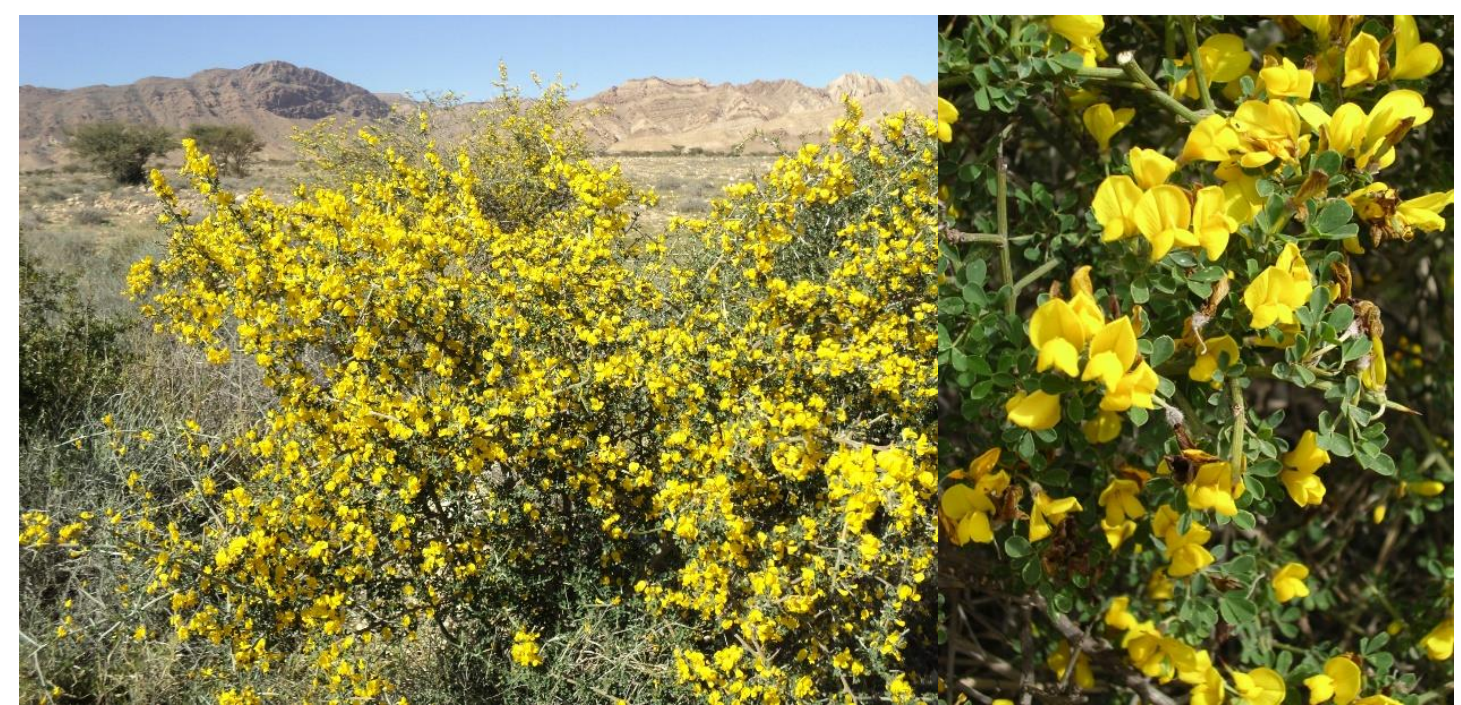

Figure 1. Calicotome villosa in Bouhedma national park (Tunisia)

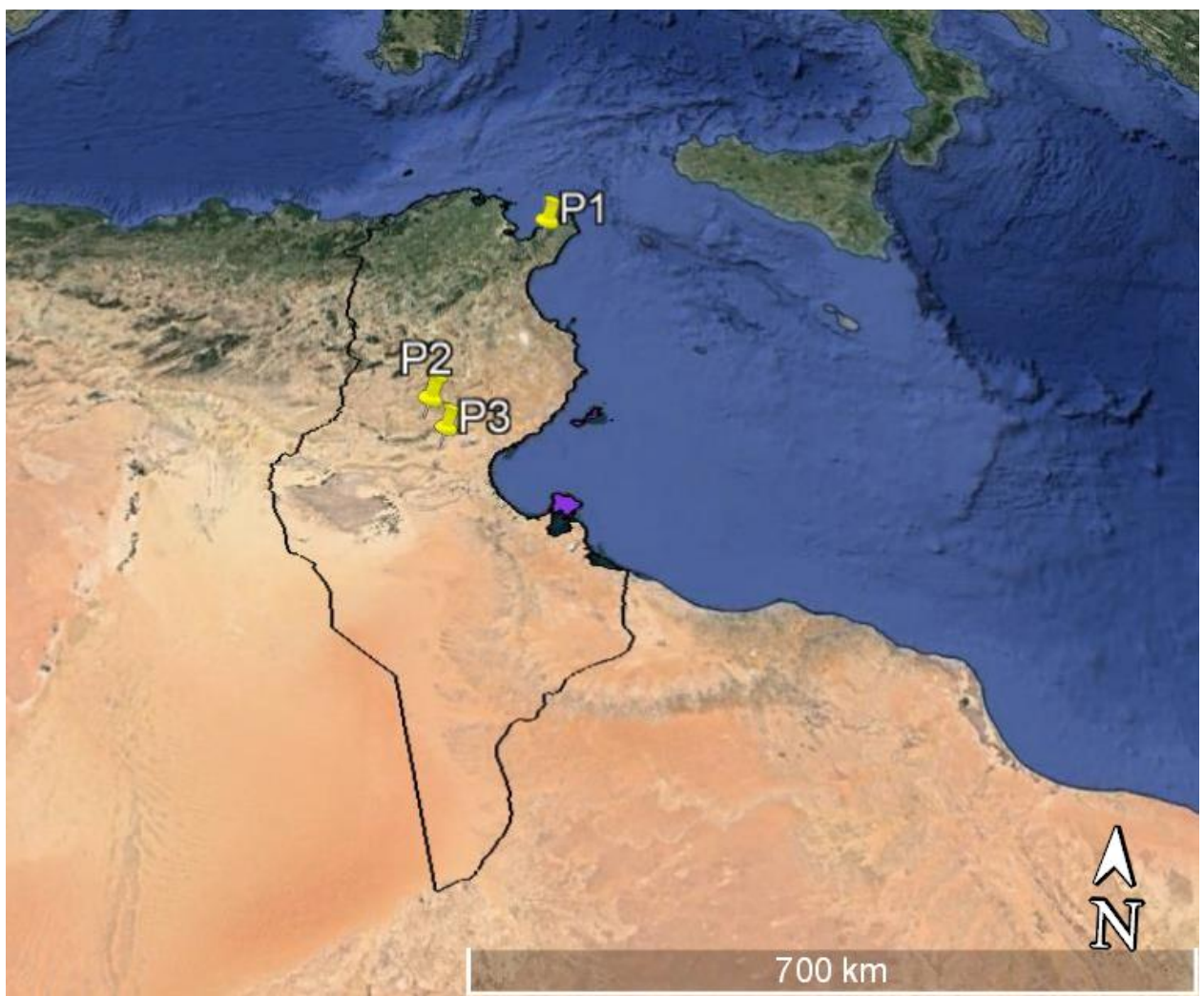

Figure 2. Tunisia map, location of the populations of spiny broom (Calicotome villosa) and sweet broom (Genista spachiana); P1: Genista spachiana of Rtiba; P2: Calicotome villosa of Meknessi; P3: Calicotome villosa of Bouhedma 
Mechergui et al.: Ecological diversity of spiny broom (Calicotome villosa (Poir.) Link) and sweet broom (Genista $\times$ spachiana) of three different provenances: chemical composition, secondary compounds of shrub leaves and responses to drought stress $-3721-$

Table 1. Location and main ecological traits of the populations of spiny broom (Calicotome villosa) and sweet broom (Genista spachiana)

\begin{tabular}{c|c|c|c|c|c|c|c}
\hline Species & Locality & Bioclimatic zone & Latitude & Longitude & Altitude (m) & $\begin{array}{c}\text { Rainfall } \\
\text { mm/year }\end{array}$ & Soil \\
\hline \multirow{2}{*}{$\begin{array}{c}\text { Calicotome } \\
\text { villosa }\end{array}$} & Meknassi & Upper arid & $34^{\circ} 35^{\prime} \mathrm{N}$ & $9^{\circ} 34^{\prime} \mathrm{E}$ & 150 & $200-250$ & $\begin{array}{c}\text { Silty, loam, very } \\
\text { stony }\end{array}$ \\
\cline { 2 - 8 } & Bouhedma & Upper arid & $34^{\circ} 28^{\prime} \mathrm{N}$ & $9^{\circ} 38^{\prime} \mathrm{E}$ & 200 & $150-200$ & $\begin{array}{c}\text { Calcareous with } \\
\text { rock outcrops, } \\
\text { very stony }\end{array}$ \\
\hline $\begin{array}{c}\text { Genista } \\
\text { spachiana }\end{array}$ & Rtiba & Lower semi arid & $36^{\circ} 53^{\prime} \mathrm{N}$ & $10^{\circ} 45^{\prime} \mathrm{E}$ & 50 & $400-500$ & $\begin{array}{c}\text { Deep silty sandy } \\
\text { loam }\end{array}$ \\
\hline
\end{tabular}

\section{Determination of secondary compounds}

Total phenols, measured by the Folin-Ciocalteu reagent, and total tannins were analyzed according to the procedure described by Makkar et al. (1993). The results are expressed in tannic acid equivalent per kilogram of dry matter. Condensed tannins were determined by oxidation in the butanol-HCl reagent in the presence of a ferric reagent using the technique of Porter et al. (1986). The experiments were conducted using three replicates.

\section{Morphology of Calicotome villosa and Genista spachiana and germinative capacity under salinity and water stress}

\section{Seeds harvesting of Calicotome villosa and Genista spachiana}

The Calicotome villosa seeds are harvested in summer of 2018 (July) from two sites in central Tunisia, Meknassi and Bouhedma national park (Fig. 3). This zone belongs to the arid bio-climate with an average temperature of 25 to $35^{\circ} \mathrm{C}$ and a rainfall of 100 to $350 \mathrm{~mm}$. The soil type is limestone for meknassi and sand for Bouhedma. Genista spachiana seeds are harvested in summer of 2018 (July) from the north of Tunisia in Rtiba area (Fig. 4), it is located in the sub-humid bio-climate and characterized by a temperature of 15 to $25^{\circ} \mathrm{C}$ and a rainfall of 500 to $700 \mathrm{~mm}$ and a sandy soil. Seeds were extracted from fruits while soaking in water for $24 \mathrm{~h}$. Healthy seeds were sterilised with benlate $(1 \mathrm{~g} / \mathrm{l})$ for $20 \mathrm{~min}$ followed by $50 \%$ sodium hypochlorite for few minutes and rinsed thrice with distilled water.

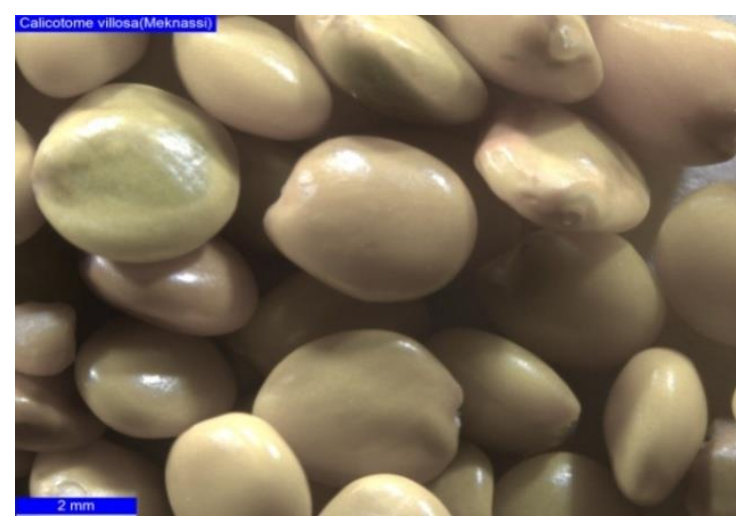

a

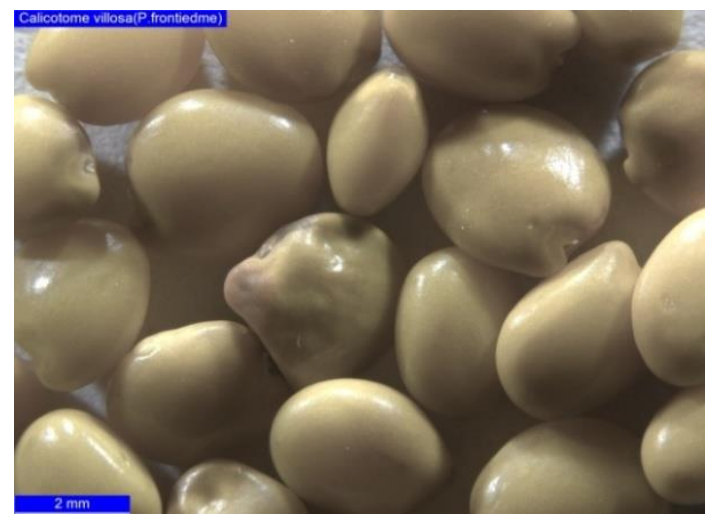

b

Figure 3. Seeds of Calicotome villosa of Bouhedma national park (a) and Calicotome villosa of Meknassi (b) 


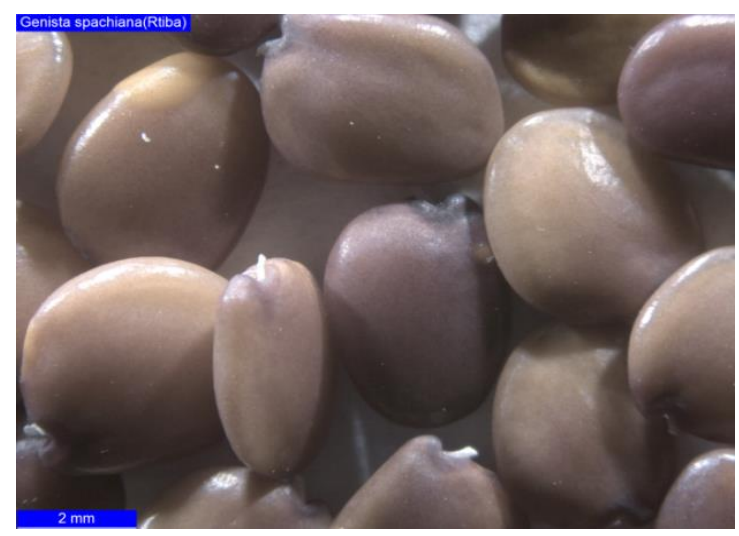

Figure 4. Seeds of Genista spachiana of Rtiba (Cap bon in Tunisia)

\section{Germinative capacity under salinity and water stress}

Seeds were placed in Petri dishes on perlite containing a polyethylene glycol solution $\left(\mathrm{PEG}_{6000}\right)$ to germinate under osmotic potentials of 0 (control sample), $-0.03,-0.1,-0.7$, -1 and $-1.6 \mathrm{MPa}$ and kept in incubator at $25{ }^{\circ} \mathrm{C}$. Seeds were placed to germinate under $\mathrm{NaCl}$ induced salt stress, at 0 (control sample), 3, 6, 9, 15 and $15 \mathrm{~g} / \mathrm{l}$. Seeds were germinated using $5 \mathrm{~mL}$ of $\mathrm{NaCl}$ or Polyethylene glycol ( $\left.\mathrm{PEG}_{6000}\right)$ induced solutions. Both osmotic were used to test salt stress and drought stress, which are two key environmental factors where these species study in northern and southern Tunisia. Germination was evaluated daily for 30 days. For each type of stress, the experiment was conducted in completely randomized design, using five replications of 20 seeds comprising 6 concentrations of $\mathrm{NaCl}$ salt and 6 concentrations of osmotic potential. Seeds were considered to be germinated when the root length reached the seed length and shoot length reached half of the seed length (Mechergui et al., 2017). The number of germinated seed was counted every day for 30 days. A seed was considered germinated when the emerging radicle elongated $2 \mathrm{~mm}$ above the seed surface (Redondo-Gómez et al., 2007).

\section{Germination expressions}

Germination of seeds in both the species were counted daily for a period of 30 days. Mean time to germination (MTG) was calculated following the formula given below:

$$
\mathrm{MTG}=\sum \mathrm{n}_{\mathrm{i}} \times \mathrm{d}_{\mathrm{i}} / \mathrm{n}
$$

where " $n$ " is the total number of germinated seeds during the test, " $n_{i}$ " is the number of germinated seeds on day " $\mathrm{d}_{\mathrm{i}}$ " and " $\mathrm{i}$ " is the number of days during the germination period of 30 days (Yousheng and Sziklai, 1985). Cumulative germination percentage (GP \%) was evaluated daily and the final value was obtained after 30 days and Kotowski's coefficient (CV) was calculated using the formula given below.

$$
\mathrm{CV}=\sum(\mathrm{n} \times \mathrm{Jn}) / \sum \mathrm{n}
$$

where " $n$ " is the total number of germinated seeds during the test, "Jn" is the number of days during the germination period (between 0 and 30 days). 
Mechergui et al.: Ecological diversity of spiny broom (Calicotome villosa (Poir.) Link) and sweet broom (Genista $\times$ spachiana) of three different provenances: chemical composition, secondary compounds of shrub leaves and responses to drought stress -3723 -

\section{Statistical analysis}

The data of the different parameter values were subjected to the analysis of variance ANOVA with SPSS 17.0 (SPSS Inc., Chicago, IL, USA). Tukey test was used to estimate significant differences between means (Mechergui et al., 2017).

\section{Results}

\section{Content of primary and secondary compounds in the sheets}

\section{Nutritional characterization of species}

The average chemical composition of the pastoral species studied is reported in Table 2. The dry matter content of the shrub leaves studied ranged from $27.98 \%$ (Calicotome villosa of Meknessi) to $41.25 \%$ (Genista spachiana of Rtiba) with very significant differences between species. The mineral content which is important at Genista spachiana of Rtiba (16.25\%). Genista spachiana of Rtiba is distinguished from other species by its high total nitrogen content (51.87\%). Overall, the composition of the parietal fraction of the substrates studied shows a very different composition $(\mathrm{P}<0.05)$. The shrub species richest in NDF is Genista spachiana of Rtiba (61.98\%DM) (Table 2). The mineral content which is high at Genista spachiana of Rtiba (41.25\%) respectively varies very significantly. The one-way ANOVA showed that dry matter (DM), mineral materials (MM), total nitrogenous materials (MAT), crude fibre (CB), neutral detregent fiber (NDF), acid detregent fiber (ADF), and acid detregent lignin (ADL) varied significantly among the three species $(P<0.001)$. The differences between chemical composition are induced by the diversity of the species in the hand and influenced by the environmental conditions in the other hand.

Table 2. Primary chemical composition of leaves of shrub species (\% of dry matter: DM)

\begin{tabular}{c|c|c|c|c|c|c|c}
\hline Species & DM & MM & MAT & CB & NDF & ADF & ADL \\
\hline Calicotome villosa of Meknessi & $28.9 \pm 5.69^{\mathrm{b}}$ & $8.6 \pm 1.09^{\mathrm{f}}$ & $36.5 \pm 5.88^{\mathrm{ab}}$ & $19.6 \pm 3.69^{\mathrm{e}}$ & $36.6 \pm 6.25^{\mathrm{a}}$ & $26.4 \pm 6.25^{\mathrm{c}}$ & $21.5 \pm 4.26^{\mathrm{d}}$ \\
Calicotome villosa of Bouhedma & $30.6 \pm 4.29^{\mathrm{d}}$ & $12.6 \pm 3.13^{\mathrm{g}}$ & $45.9 \pm 7.19^{\mathrm{b}}$ & $26.5 \pm 3.27^{\mathrm{f}}$ & $48.6 \pm 8.46^{\mathrm{a}}$ & $39.9 \pm 8.75^{\mathrm{bc}}$ & $28.5 \pm 3.22^{\mathrm{de}}$ \\
Genista spachiana of Rtiba & $41.2 \pm 6.85^{\mathrm{cd}}$ & $16.2 \pm 2.43^{\mathrm{g}}$ & $51.8 \pm 8.97^{\mathrm{ab}}$ & $31.1 \pm 5.29^{\mathrm{ef}}$ & $61.8 \pm 10.26$ & $42.7 \pm 8.34^{\mathrm{c}}$ & $34.5 \pm 4.66^{\mathrm{a}}$ \\
Level of significance & $P<0.001$ & $P<0.001$ & $P<0.001$ & $P<0.001$ & $P<0.001$ & $P<0.001$ & $P<0.001$ \\
\hline
\end{tabular}

DM: dry matter; MM: mineral materials; MAT: total nitrogenous materials; CB: Crude fibre; NDF: Neutral Detergent Fiber; ADF: Acid Detergent Fiber; ADL: Acid Detergent Lignin

\section{Anti-nutritional substance content of leaves in shrub vegetation}

The average richness of the pastoral species studied in phenolic compounds and saponins is reflected in Table 3. The average content of total phenols and total tannins shows significant variability between the species studied. Calicotome villosa from Meknassi is the species richest in phenolic compounds and total tannins with $76.25 \mathrm{~g}$ tannic acid equivalent/kg DM (Table 3). The condensed tannin content ranged from 10.68 to $15.24 \mathrm{~g}$ leucocyanidin equivalent $/ \mathrm{kg} \mathrm{DM}$. It is the weakest for Genista spachiana of Rtiba. The hydrolysable tannin content of shrub species is generally high, especially in Calycotum spinosa of Meknassi (63.58 g/kg DM). Calicotome villosa de Bouhedma is the most abundant species in saponin with an average of $10.32 \mathrm{~g}$ diosgenin equivalent $/ \mathrm{kg}$ DM. The hemolytic activity of saponins is an indicator of their biological effect. Genista spachiana of Rtiba saponins have the most intense hemolytic activity 
Mechergui et al.: Ecological diversity of spiny broom (Calicotome villosa (Poir.) Link) and sweet broom (Genista $\times$ spachiana) of three different provenances: chemical composition, secondary compounds of shrub leaves and responses to drought stress - 3724 -

(Table 3). We recorded a strong positive correlation between the condensed tannin content and mineral matter content $(r=0.71 ; P=0.001)$ and between the ADF lignocellulose content and the total phenol content $)(r=0.93 ; P=0.001)$, as well as between the saponin and dry matter content $(r=0.68 ; P=0.001)$. It is important to note that the hemolytic activity of saponins is positively correlated with the content of condensed tannins $(r=0.78 ; P=0.001)$ and with minerals $(r=0.86 ; P=0.001)$. The one-way ANOVA showed that total phenols (PhT), Total tannins (TT), condensed tannins (TC), saponins (sap), hydrolysable tannins (TH), and hemolytic activity of saponins $(\mathrm{AH})$ varied significantly among the three species $(P<0.01)$. The differences between anti-nutritional substance are induced by the diversity of the species in the hand and influenced by the environmental conditions in the other hand.

Table 3. Anti-nutritional substance content of leaves in shrub vegetation

\begin{tabular}{c|c|c|c|c|c|c}
\hline Species & PhT & TT & TC & Sap & TH & AH \\
\hline Calicotome villosa of Meknessi & $112.2 \pm 15.36^{\mathrm{a}}$ & $76.2 \pm 2.35^{\mathrm{b}}$ & $15.2 \pm 2.48^{\mathrm{d}}$ & $7.5 \pm 2.98^{\mathrm{ef}}$ & $63.5 \pm 5.41^{\mathrm{bc}}$ & $8.6 \pm 2.77^{\mathrm{e}}$ \\
Calicotome villosa of Bouhedma & $125.3 \pm 14.24^{\mathrm{a}}$ & $74.2 \pm 4.12^{\mathrm{b}}$ & $11.2 \pm 3.44^{\mathrm{d}}$ & $10.3 \pm 1.20^{\mathrm{de}}$ & $59.3 \pm 9.68^{\mathrm{c}}$ & $9.6 \pm 1.33^{\mathrm{f}}$ \\
Genista spachiana of Rtiba & $98.6 \pm 8.65^{\mathrm{a}}$ & $65.9 \pm 4.15^{\mathrm{b}}$ & $10.6 \pm 2.35^{\mathrm{de}}$ & $6.6 \pm 1.02^{\mathrm{f}}$ & $48.6 \pm 6.55^{\mathrm{c}}$ & $19.2 \pm 3.55^{\mathrm{d}}$ \\
Level of significance & $P<0.01$ & $P<0.01$ & $P<0.01$ & $P<0.01$ & $P<0.01$ & $P<0.01$ \\
\hline
\end{tabular}

PhT: Total phenols (in g equivalent tannic acid/kg DM); TT: Total tannins (in g equivalent tannic acid/kg DM); TC: Condensed tannins (in g equivalent leucocyanidine/kg DM); Sap: Saponins (in g equivalent diosgenin $/ \mathrm{kg} \mathrm{DM}$ ); TH: Hydrolysable tannins (g/kg DM); AH: Hemolytic activity of saponins (\%)

\section{Digestibilities and energy and nitrogen values of forage shrub leaves}

The forage value of the foliage of the shrubs studied varies from $0.94 \mathrm{UFL} / \mathrm{kg}$ DM for Calicotome villosa of Meknessi to $1.09 \mathrm{UFL} / \mathrm{kg}$ DM for Genista spachiana of Rtiba for whom the MAD are 287.89 (Table 4). These shrub leaves are characterized by a calculated average digestibility of organic matter ranging from 55.32 for Calicotome villosa of Meknessi to $71.95 \%$ Genista spachiana of Rtiba. Calicotome villosa leaves are the richest in digestible nitrogenous matter $(296.6 \mathrm{~g} / \mathrm{kg} \mathrm{DM})$. The one-way ANOVA showed that Digestibility (MO) and energy (UFL and UFV) and nitrogen values (MAD) of fodder shrub leaves varied significantly among the three species $(P<0.001)$. The differences between digestibilities and energy and nitrogen values are induced by the diversity of the species in the hand and influenced by the environmental conditions in the other hand.

\section{Effects of salt stress on germination}

The effect of salinity on germination of Calicotome villosa and Genista spachiana seeds are presented in Table 5. Germination in distilled water was the highest. However, it decreased significantly with an increase in $\mathrm{NaCl}$ concentrations (Table 5). Seeds germinated rapidly in distilled water during the first five days and decreased gradually with increase in salinity, the highest germination was recorded $(82 \%)$ in distilled water of Genista spachiana of Rtiba and the lowest (31\%) corresponding of $15 \mathrm{~g} / \mathrm{l} \mathrm{NaCl}$ from Calicotome villosa of Bouhedma. There was a strong negative relationship between germination and salinity. The Germination velocity calculated using the Kotowski index (equation 2) showed that the rate decreased with an increase in salinity (Table 5). Results of ANOVA showed that salt stress ( $\mathrm{NaCl}$ treatments) had a significant effect on germination percentage (Table 6) and on mean germination time calculated using equation (2). Germination was significantly reduced by high $\mathrm{NaCl}$ levels and there were no great differences in final germination percentage between 3 and $9 \mathrm{~g} / \mathrm{l}$, thus 
Mechergui et al.: Ecological diversity of spiny broom (Calicotome villosa (Poir.) Link) and sweet broom (Genista $\times$ spachiana) of three different provenances: chemical composition, secondary compounds of shrub leaves and responses to drought stress $-3725-$

germination percentage was reduced with increasing $\mathrm{NaCl}$ to levels above $12 \mathrm{~g} / \mathrm{l}$. A two-way ANOVA of the germination rate indicated a significant effect of salinity but not an interaction between species and salinity (Table 6). The differences between germination capacity under salt stress are induced by the diversity of the species in the hand and influenced by the environmental conditions in the other hand.

Table 4. Digestibility and energy and nitrogen values of fodder shrub leaves

\begin{tabular}{c|c|c|c|c}
\hline Species & Digestibility MO $(\%)$ & UFL & UFV & MAD \\
\hline Calicotome villosa of Meknessi & $55.3 \pm 2.25^{\mathrm{b}}$ & $0.9 \pm 6.35^{\mathrm{c}}$ & $0.9 \pm 0.58^{\mathrm{cd}}$ & $286.3 \pm 12.35^{\mathrm{a}}$ \\
Calicotome villosa of Bouhedma & $61.3 \pm 3.35^{\mathrm{b}}$ & $1.0 \pm 4.16^{\mathrm{c}}$ & $1.0 \pm 0.65^{\mathrm{d}}$ & $296.6 \pm 13.23^{\mathrm{a}}$ \\
Genista spachiana of Rtiba & $71.9 \pm 5.62 \mathrm{~b}$ & $1.0 \pm 6.87^{\mathrm{c}}$ & $1.0 \pm 0.25^{\mathrm{d}}$ & $278.8 \pm 22.15^{\mathrm{a}}$ \\
Level of significance & $P<0.001$ & $P<0.001$ & $P<0.001$ & $P<0.001$ \\
\hline
\end{tabular}

UFL: Feed Unit Milk/kg DM; UFV: Feed Unit Milk/kg DM; MAD: Digestible nitrogenous matter (g/kg $\mathrm{DM})$

Table 5. Mean percentage germination of Calicotome villosa and Genista spachiana seeds after transfer from 0, 3, 6, 9, 12 and $15 \mathrm{~g} / \mathrm{l} \mathrm{NaCl}$ at $25^{\circ} \mathrm{C}$

\begin{tabular}{c|c|c|c|c|c|c}
\hline \multirow{2}{*}{ Species } & \multicolumn{5}{c}{ NaCl (g/l) } \\
\cline { 2 - 7 } & $\mathbf{0}$ & $\mathbf{3}$ & $\mathbf{6}$ & $\mathbf{9}$ & $\mathbf{1 2}$ & $\mathbf{1 5}$ \\
\hline Calicotome villosa of Meknassi & $75 \pm 10.8^{\mathrm{a}}$ & $60 \pm 3.1^{\mathrm{b}}$ & $49 \pm 7.6^{\mathrm{cd}}$ & $50 \pm 6.1^{\mathrm{c}}$ & $47 \pm 2.5^{\mathrm{e}}$ & $32 \pm 7.5^{\mathrm{f}}$ \\
Calicotome villosa of Bouhedma & $78 \pm 13.7^{\mathrm{a}}$ & $51 \pm 8.2^{\mathrm{b}}$ & $48 \pm 6.8^{\mathrm{c}}$ & $41 \pm 5.3^{\mathrm{cd}}$ & $35 \pm 4.7^{\mathrm{ef}}$ & $31 \pm 7.9^{\mathrm{f}}$ \\
Genista spachiana of Rtiba & $82 \pm 15.1^{\mathrm{a}}$ & $61 \pm 7.9^{\mathrm{b}}$ & $60 \pm 4.4^{\mathrm{bc}}$ & $56 \pm 6.5^{\mathrm{d}}$ & $42 \pm 3.7^{\mathrm{e}}$ & $37 \pm 5.3^{\mathrm{ef}}$ \\
\hline
\end{tabular}

Different letters indicate significant difference among treatment means ( $\mathrm{p}<0.05$; Tukey test)

${ }^{a b c}$ Values in the same row with the same superscript are not significantly different $(P>0.05)$

Table 6. Two-way ANOVA of the effects of salinity $(S)$, Species $(T)$, and their interaction on germination characteristics of Calicotome villosa and Genista spachiana

\begin{tabular}{c|c|c|c|c}
\hline Variable & Characteristics of germination & $\boldsymbol{F}$-value & $\boldsymbol{P}$-value & Signification \\
\hline \multirow{3}{*}{ Species } & Germination percentage & 1.985 & 0.145 & NS \\
& Kotowski coefficient & 0.591 & 0.557 & NS \\
& Mean time to germination & 4.976 & 0.009 & $* *$ \\
\hline \multirow{3}{*}{ Concentration } & Germination percentage & 11.673 & 0.000 & $* * *$ \\
& Kotowski coefficient & 12.503 & 0.000 & $* * *$ \\
& Mean time to germination & 29.097 & 0.000 & $* * *$ \\
\hline \multirow{3}{*}{ Species $\times$ concentration } & Germination percentage & 0.225 & 0.993 & NS \\
& Kotowski coefficient & 0.234 & 0.992 & NS \\
& Mean time to germination & 1.259 & 0.270 & NS \\
\hline
\end{tabular}

Significant difference from control at $* P<0.05, * * P<0.01, * * * P<0.001$ by Tukey's test. NS $=$ not significant

\section{Effects of osmotic potential on germination}

Osmotic potential significantly $(P<0.001)$ affected the percentage of germination of Calicotome villosa and Genista spachiana (Table 7). Germination percentage decreased significantly with an increase in osmotic potential. Seeds germinated rapidly in distilled 
Mechergui et al.: Ecological diversity of spiny broom (Calicotome villosa (Poir.) Link) and sweet broom (Genista $\times$ spachiana) of three different provenances: chemical composition, secondary compounds of shrub leaves and responses to drought stress $-3726-$

water during the initial days. Germination rate decreased with increasing levels of osmotic potential (Table 7). The highest germination percentage was recorded with distilled water followed by $0,-0.03,-0.1,-0.7,-1$ and $-1.6 \mathrm{MPa}$. However, at $-0.03 \mathrm{MPa}$ Calicotome villosa seeds from Meknassi had a germination rate higher than control. Germination percentage and osmotic potential are negatively correlated in both the species. The differences between germination capacity under osmotic potential are induced by the diversity of the species in the hand and influenced by the environmental conditions in the other hand.

\section{Germination index}

The Kotowski index showed that the rate decreased with an increase in osmotic potential. In all the provenances of Calicotome villosa and Genista spachiana, water stress had a significant effect $(P<0.001)$ on germination, mean germination time (MGT) and the Kotowski coefficient (Table 8). Germination percentage and speed decreased with decrease in water potential. Germination percentage for Calicotome seeds from Meknassi, the highest among all treatments (79 was at $0.03 \mathrm{MPa}$ ). Also, germination percentage exceeded $50 \%$ at $-1 \mathrm{MPa}$. A two-way ANOVA indicated a significant effect of osmotic potential on germination rate, but not for the interaction between osmotic potential and species germination percentage (Table 8).

Table 7. Mean percentage germination of Calicotome villosa and Genista spachiana seeds at $0,-0.03,-0.1,-0.7,-1$ and $-1.6 \mathrm{MPa}$ at $25^{\circ} \mathrm{C}$

\begin{tabular}{c|c|c|c|c|c|c}
\hline \multirow{2}{*}{ Species } & \multicolumn{7}{c}{ Osmotic potential (MPa) } \\
\cline { 2 - 7 } & $\mathbf{0}$ & $\mathbf{- 0 . 0 3}$ & $\mathbf{- 0 . 1}$ & $\mathbf{- 0 . 7}$ & $\mathbf{- 1}$ & $\mathbf{- 1 . 6}$ \\
\hline Calicotome villosa of Bouhedma & $78 \pm 4.1^{\mathrm{a}}$ & $65 \pm 10.8^{\mathrm{ab}}$ & $65 \pm 8.9^{\mathrm{ab}}$ & $56 \pm 3.6^{\mathrm{c}}$ & $41 \pm 9.4^{\mathrm{d}}$ & $30 \pm 4.7^{\mathrm{e}}$ \\
Calicotome villosa of Meknassi & $74 \pm 4.8^{\mathrm{ab}}$ & $79 \pm 4.3^{\mathrm{a}}$ & $65 \pm 6.8^{\mathrm{b}}$ & $56 \pm 6.5^{\mathrm{c}}$ & $43 \pm 8.7^{\mathrm{d}}$ & $38 \pm 7.5^{\mathrm{e}}$ \\
Genista spachiana of Rtiba & $78 \pm 4.0^{\mathrm{a}}$ & $65 \pm 6.8^{\mathrm{ab}}$ & $55 \pm 4.7^{\mathrm{b}}$ & $48 \pm 8.7^{\mathrm{c}}$ & $42 \pm 9.5^{\mathrm{cd}}$ & $40 \pm 9.6^{\mathrm{d}}$ \\
\hline
\end{tabular}

Different letters indicate significant difference among treatment means $(\mathrm{p}<0.05$ : Tukey test)

${ }^{\text {abcde }}$ Values in the same row with the same superscript are not significantly different $(P>0.05)$

Table 8. Two-way ANOVA of the effects of Osmotic potential (S), Species (T), and their interaction on germination characteristics of Calicotome villosa and Genista spachiana

\begin{tabular}{c|c|c|c|c}
\hline Variable & Characteristics of germination & $\boldsymbol{F}$-value & $\boldsymbol{P}$-value & Significance \\
\hline \multirow{3}{*}{ Species } & Germination percentage & 0.570 & 0.568 & NS \\
& Kotowski coefficient & 3.782 & 0.027 & $*$ \\
& Mean time to germination & 5.040 & 0.009 & $* *$ \\
\hline \multirow{3}{*}{ Concentration } & Germination percentage & 14.051 & 0.000 & $* * *$ \\
& Kotowski coefficient & 6.330 & 0.000 & $* * *$ \\
& Mean time to germination & 14.731 & 0.000 & $* * *$ \\
\hline \multirow{3}{*}{ Species $\times$ concentration } & Germination percentage & 0.436 & 0.924 & NS \\
& Kotowski coefficient & 0.766 & 0.661 & NS \\
& Mean time to germination & 2.340 & 0.019 & $*$ \\
\hline
\end{tabular}

Significant difference from control at $* P<0.05, * * P<0.01, * * * P<0.001$ by Tukey's multiple tests. $\mathrm{NS}=$ not significant $(P>0.05)$ 
Mechergui et al.: Ecological diversity of spiny broom (Calicotome villosa (Poir.) Link) and sweet broom (Genista $\times$ spachiana) of three different provenances: chemical composition, secondary compounds of shrub leaves and responses to drought stress -3727 -

\section{Discussion}

\section{Content of primary and secondary compounds in the sheets}

\section{Nutritional characterization of species}

Despite the very wide use of concentrated feed in animal nutrition, coarse fodder remains the basis of ruminant feed intake. Spontaneous vegetation, particularly woody vegetation, is an important contribution to meeting the needs of the ruminants that live there. To make optimal use of the nutritional potential of this natural vegetation, it is necessary to know its nutritional value. The season influences the nutritive and antinutritive components of forage species in the Himalayan region (Katoch et al., 2012). Seed size can be used as a parameter for predicting germination and seedling growth rate both in nursery and field conditions (Mohamed et al., 2018). The dietary value of a forage is generally judged on the basis of its content of potentially digestible nutrients (mainly energy, nitrogen and minerals) and on the presence of undesirable compounds such as lignin. The foliage of the ten identified shrubs had an DM content of less than $50 \%$, which confirm DM the results of González-Andrés and Ortiz (1996) who observed the same trend with Mediterranean shrub species. This results in the availability of forage shrubs, which regularly provide standing biomass throughout the year, unlike herbaceous species that dry up in summer. Indeed, analyses of the chemical composition of shrub leaves have shown low average dry matter levels, which makes them a water-rich foodstuff, which does not dry out in summer (lean season), and also remains present during the winter period, these two periods being critical for livestock for which herbaceous vegetation is very limited, making them a year-round food resource. The mineral content is medium to high for some shrub leaves (Calicotome villosa de Meknassi (8.67\%), Calicotome villosa de Bouhedma (12.65\%) and Genista spachiana de Rtiba (16.25\%). Different results were recorded by Boubaker et al. (2004) for shrub leaves from northwest Tunisia, for which low mineral values were recorded (2.8-6.4\% DM). According to Spears (1994), the concentration of mineral elements in plants varies greatly with soil type, climate and stage of maturity. The majority of shrub leaves sampled by Boubaker et al. (2004) in northwestern Tunisia did not exceed 10\% DM in MAT, as did those analyzed in arid (Silva-Pando et al., 1999) or semi-arid (Ben Salem, 2000) areas. The MAT content is highest in Genista spachiana (41.25\% DM). Indeed, leguminous fodder and shrubs are very often used as livestock feed in many parts of the world, mainly because of their high protein content (Ammar et al., 2004). Given the high MAT content, the use of these legumes is indicated as a protein supplement to poor quality fodder and fibrous by-products. In our case, the MAT content of the species in the first two groups is higher than the minimum level of 7-8\% DM required for rumen functioning to ensure maximum metabolic activity and adequate feeding of ruminants (Van Soest, 1994; Norton, 2003). According to Boughalleb et al. (2019) total phenols of C. Villosa ranging from 34.6 to $45.1 \mathrm{mg} \mathrm{GAE} / \mathrm{g}$ DW. Flavonoids varied from 21.4 to $34.1 \mathrm{mg}$ QRE/g DW. High-maintained storage protein content (50.2\% DW) occurred in C. villosa seeds. Globulins were the major proteins $(47.6 \%$ of total proteins). Condensed tannins may play an important role in the defense system of seeds that are subjected to oxidative damage induced by abiotic factors (Troszynska and Ciska, 2002). In legume seeds, tannins are considered as antinutritional compounds (Mohan et al., 2016). Boughalleb et al. (2019) showed that the total condensed tannins was registered $0.15 \pm 0.01 \mathrm{CTE} / \mathrm{g} \mathrm{DW}$. These values remained higher compared to those obtained for the leguminous L. Sativus (0.001-0.004 CTE/g DW) (Rybiński et al., 
Mechergui et al.: Ecological diversity of spiny broom (Calicotome villosa (Poir.) Link) and sweet broom (Genista $\times$ spachiana) of three different provenances: chemical composition, secondary compounds of shrub leaves and responses to drought stress - 3728 -

2018) and similar to those reported for the extract of Prosopis farcta ( $0.15 \mathrm{mg} \mathrm{CE} / \mathrm{g}$ DW) by Lajnef et al. (2015).

\section{Anti-nutritional substance content of leaves in shrub vegetation}

The total wall contents of forage shrub leaves (NDF) in our study, which ranged from 36 to $61 \% \mathrm{DM}$, are generally comparable to those reported by other authors (Makkar and Singh, 1991; Ammar et al., 2005. However, there are some differences to note. This high NDF fraction rate could be explained by the environmental conditions in the semi-arid region. Indeed, Pascual et al. (2000) indicate that high temperatures and low precipitation tend to increase the parietal fraction (NDF) and decrease the soluble content of plants. As for the results of the lignin concentrations of these different samples, they remain high for all species and have good forage values ranging from 0.94 to 1.09 UFL and from 0.91 to $1.06 \mathrm{UFV}$ ). Tannins are anti-nutritional substances that are involved in defence mechanis DM, they protect the plant against attacks by pathogenic microorganis DM (fungi and bacteria) and herbivorous predators (animals or foliar insects), they therefore have a very important agronomic advantage (Rira, 2006). Their presence may also reflect a response to stress (scarcity of rainfall, unfavourable soil quality associated with an increase in tannin levels). The large variation in tannin content in woody species has been observed by many researchers (Kaitho et al., 1998). In the study of chemical composition of Genista aspalathoides from North Western Tunisia, Selmi et al. (2020) showed that the species contains $34.1 \%$ of dry matter (DM), $94.1 \%$ organic matter $(\mathrm{OM}), 2.75 \%$ crude protein $(\mathrm{CP}), 2.37 \%$ fat and $5.79 \%$ crude fiber (CF), 36.1\% ADF, 45.1\% NDF, 30.3\% ADL, $21.5 \mathrm{mg}$ GAE/g DM (Polyphenols), $2.79 \mathrm{mg}$ QE/g MD (Flavonoïds), and $5.82 \mathrm{mg} \mathrm{CE} / \mathrm{g}$ MD (Condensed tannins). Similar results were found by Selmi et al. (2018).

\section{Digestibilities and energy and nitrogen values of forage shrub leaves}

The results of the total concentration of condensed tannins show significantly different $(\mathrm{P}<0.001)$ and low values compared to those obtained in the work of Ammar et al. (2004, 2009) and Alvarez et al. (2005) for shrub leaves from northern Spain. Kumar and Vaithiyanathan (1990) report beneficial effects of condensed tannins in ruminant feeds $(<50 \mathrm{~g} / \mathrm{Kg} \mathrm{DM})$ as they promote the absorption of amino acids in the small intestine by protecting them from the effects of gastric juice. Zimmer and Cordesse (1996) also report that the same dose of tannins extracted from chestnuts improves the quantitative degradation of protein in sheep. Thus, the species studied, based on their moderate content of total and condensed tannins, may have a nutritional advantage for the animal. The chemical composition of the foliage of forage plants varies between species, this may be largely due to genotypic factors because the accumulation of nutrients in plants is a specific property (Minson, 1990) that varies between species and genera. To our knowledge, our work is the first to focus on the determination of saponin content and hemolytic activity of local shrub species. This content varied between 7 and $10 \mathrm{~g}$ diosgenin equivalent $/ \mathrm{kg}$ DM. The planting of fodder shrubs in order to exploit their leaves may present, in Tunisia, an interesting alternative to face the problem of fodder deficit. In this context, the choice of species to be planted must be based both on the determination of forage values (based on the determination of the primary chemical composition) of the leaves and on the content of secondary compounds. For example, Calicotome villosa from Meknassi and Bouhedma and 
Genista from Rtiba have a high content of MAD and high UFL, UFV values, but it has high tannin contents that reduce the availability of nutrients in this species to the animal. In the study of chemical composition of Calicotome villosa in Algeria, MebiroukBoudechiche et al. (2015) showed that the species contains $282 \mathrm{~g} / \mathrm{kg}$ of dry matter (DM), $73.9 \mathrm{~g} / \mathrm{kg} \mathrm{MS}$ of mineral matter (MM), $337 \mathrm{~g} / \mathrm{kg}$ MS of total nitrogenous matter (MAT), $17.6 \mathrm{~g} / \mathrm{kg}$ DM of crude fibre (CF), $119.43 \mathrm{~g}$ eq. tannic acid/kg MS of total phenols, $83.68 \mathrm{~g}$ eq. tannic acid/kg DM of total tannins.

\section{Effects of salt stress on germination}

In arid ecosystems, salinity and moisture availability are among the main factors influencing germination. Indeed, the study of germination patterns of plant species would increase our understanding of their ability to colonize marginalized areas in contrasting environments (Tlili et al., 2019).

Salinity stress can affect seed germination through osmotic effects (Welbaum et al., 1990) and by ion-toxicity (Huang and Reddman, 1995). More than 50\% of the seeds of Calicotome villosa and Genista spachiana germinated at lower salt stress (9 g/l) and at the lower water potential $(-1 \mathrm{MPa})$. This suggested that these species can germinate under low water availability. In study of effect of salinity Mechergui et al. (2017) showed that Calicotome villosa and Genista spachiana can tolerate salinity of up to $15 \mathrm{~g} / \mathrm{l}$ of salt (31-37\% germination at $15 \mathrm{~g} / \mathrm{l})$ and also tolerate drought (30-40\% germination at $-1.6 \mathrm{MPa}$. This tolerance of water potential (-0.8 $\mathrm{MPa})$ was also observed in other Fabaceae and desert species like Retama raetam (Youssef, 2009). Generally, salt stress affected the germination capacity and speed of Calicotome and Genista seeds, these results agree with these of Lachiheb et al. (2004). In our study, seed germination percentage was higher in $\mathrm{NaCl}$ than in PEG at the same water potential. Some $\mathrm{He}$ et al. (2009) demonstrated that $\mathrm{NaCl}$ and $\mathrm{PEG}$ adversely affected germination, but $\mathrm{NaCl}$ had a less inhibitory effect on seed germination than an iso-osmotic solution of PEG. In contrast, Katembe et al. (1998) found that higher concentrations of $\mathrm{NaCl}$ ($1 \mathrm{MPa}$ ) were more inhibitory to germination of two Atriplex species (A. halunus and A. numelaria). Seeds of Calicotome villosa and Genista spachiana responded in two characteristic ways to salinity: first, germination was reduced, second at very low concentrations, germination was stimulated. Although higher salinity generally decreases germination, the detrimental effect of salinity is less severe at the optimum germination osmotic potential. Salt stress decreased both the rate and percentage of germination of Calicotome villosa and Genista spachiana. Several other studies revealing those halophytes, as well as glycophytes, are sensitive to salt during the germination stage (Katembe et al., 1998; Khan et al., 2002; Gorai and Neffati, 2007; Gorai et al., 2011). Considering the percentage of seeds that germinated at $-1 \mathrm{MPa}$ and $12 \mathrm{~g} / \mathrm{l}$, we conclude that these two fabaceae species are well adapted to germinate under conditions of water and salt stresses. These abiotic stresses are typical of the environments in which they grow. Where it grows and lives. Arid lands of Tunisia are widely affected by desertification, which is caused particularly by the degradation of the vegetation cover, deforestation and drought. According to Tlili et al. (2019) under control conditions $(0 \mathrm{MPa})$, the highest percentage of germination was reached for $\mathrm{A}$. mollis. However, germination decreased significantly at $-0.75 \mathrm{MPa}(\mathrm{NaCl}$ and $\mathrm{PEG})$. It is generally assumed that halophytes germinate better at low than at high salinities, but this varies according to the species (Ungar, 1995). Previous studies on Atriplex species, including A. micrantha (Liu et al., 2007; Yan and Wei, 2014), A. halimus (Muñoz- 
Mechergui et al.: Ecological diversity of spiny broom (Calicotome villosa (Poir.) Link) and sweet broom (Genista $\times$ spachiana) of three different provenances: chemical composition, secondary compounds of shrub leaves and responses to drought stress - 3730 -

Rodríguez et al., 2012) and A. portulacoides (Muñoz-Rodríguez et al., 2017) found a salt tolerance in their germination responses and an inhibitory effect of the bracteoles.

\section{Effects of osmotic potential on germination}

The high ability of Calicotome villosa and Genista spachiana germinate over a wide range of environmental conditions provides an opportunity to contribute to future reforestation. Calicotome villosa seeds from Meknassi had a higher rate of germination at $-0.03 \mathrm{MPa}$ than at $0 \mathrm{MPa}$ compared with non-stressed seeds. Seed germination percentage and the Kotowski coefficient generally decreases as soil water potential decreases (Evans and Etherington, 1990). Germination of three deciduous semi-shrubs of Artemisia was inhibited severely in $\mathrm{PEG}_{6000}$ solutions at $-1.2 \mathrm{MPa}$ (Tobe et al., 2000). An increase in osmolality of PEG 6000 solutions results in decreasing both the percentage and rate of germination Calicotome villosa and Genista spachiana, indicating that water stress inhibits germination, which is in agreement with the germination behaviour of most species (Tobe et al., 2000; Gorai et al., 2009; Maraghni et al., 2010). It can be concluded that seeds of Calicotome villosa and Genista spachiana germinate have the ability to tolerate salt stress after exposure to $\mathrm{NaCl}$ solutions and osmotic potential concentrations. Further investigations are necessary to understand the early establishment of this species under field conditions and to determine if there are differences between the seed germination stage and early seedling growth in response to salinity and drought stress. These results corroborate the findings obtained by Aiazzi et al. (1992) showed that seeds of $A$. cordobens is had droughtinduced dormancy at low temperature, but at $30{ }^{\circ} \mathrm{C}$ seeds may lose viability. In contrast, Mandana et al. (2017) found that A. halimus is highly tolerant to water stress with a final germination of ca. $31 \%$ at $-1.5 \mathrm{MPa}$ as compared to salt stress with only a few seeds that germinated (3\%). These authors suggested that A. halimus seeds were more tolerant to salinity than water stress, which would help in using this species in rehabilitation programs of degraded lands. Sharma (1976) suggested that among semiarid plant species most of Atriplex species decreased their germination when seeds exposed to less negative osmotic potential $(-1.5 \mathrm{MPa})$. William et al. (1998) showed that imbibition processes, germination and root elongation of A. prostrate were inhibited at low osmotic potential $(-1 \mathrm{MPa})$. These traits were more inhibited by salinity than by water stress at $-1 \mathrm{MPa}$. This result is not consistent with study of Tlili et al. (2019) for A. mollis.

\section{Conclusions}

The use of fodder shrub leaves in the feeding of ruminants is an interesting food alternative given the fodder deficit encountered in Tunisia and the increase in the prices of raw materials formulating concentrated feed. Indeed, the nitrogen and energy values of these shrub leaves can cover the needs of ruminants for a long period of the year and especially during the lean season. Given the overgrazing proble DM in the study area, it would be interesting to start planting some shrubs. In this context, this study may be of interest in DM of the choice of species to be planted. Thus, chemical analysis revealed that the total nitrogen content of the leaves of the species studied is interesting. This makes it possible to consider the leaves of this shrub as an additive nitrogen supplement with fodder or fibrous by-products, however, its high content of tannins and total phenols should be taken into account by combining certain products or applying certain 
Mechergui et al.: Ecological diversity of spiny broom (Calicotome villosa (Poir.) Link) and sweet broom (Genista $\times$ spachiana) of three different provenances: chemical composition, secondary compounds of shrub leaves and responses to drought stress $-3731-$

methods to deactivate them: use of polyethylene glycol (PEG), essential oils, drying.... Genista spachiana is can tolerant to salt stress up to $\mathrm{NaCl}$ concentration of $12 \mathrm{~g} / \mathrm{l}$. Though germination rate in Calicotome villosa and Genista spachiana decrease with increasing concentrations of PEG, seeds of the two species germinated to 30 and to $40 \%$ at -1.6 MPa. Thus, it is concluded from the study that both the species can tolerate water and salt stresses very well. Further it is also inferred that Genista spachiana provenance from Rtiba is more tolerant than Calicotome villosa provenance to water stress with a germination rate of $40 \%$ at water potential of $-1.6 \mathrm{MPa}$. In order to progress in this field, it would necessary to analyze total phenolics and total tannins content of the different plant tissues, detect other inhibitory compounds and carry out bioassay in the presence and absence of tannin-complexing agents, such as PEG, to estimate tannin activity.

Conflict of interests. The authors declare that they have no conflict of interests.

\section{REFERENCES}

[1] Aiazzi, M. T., Argüello, J. A. (1992): Dormancy and germination studies on dispersal unites of Atriplex Cordobensis (gandoger and Stucker) (Chenopodiaceae). - Seed Science and Technology 20: 401-407.

[2] Alhage, J., Elbitar, H., Taha, S., Guegan, J. P., Dassouki, Z., Vives, T., Benvegnu, T. (2018): Isolation of bioactive compounds from Calicotome villosa stems. - Molecules 23(4): 851-870.

[3] Alvarez Del Pino, M., Hervas, G., Mantecon, A. R., Giraldez, F. J., Frutos, P. (2005): Comparison of biological and chemical methods, and internal and external standards, for assaying tannins in Spanish shrub species. - Journal of the Science of Food and Agriculture 85: 583-590.

[4] Ammar, H., Lopez, S., Gonzalez, J. S., Ranilla, M. J. (2004): Seasonal variations in the chemical composition and in vitro digestibility of some Spanish leguminous shrub species. - Animal Feed Science and Technology 115: 327-340.

[5] Ammar, H., López, S., González, J. S. (2005): Assessment of the digestibility of some Mediterranean shrubs by in vitro techniques. - Animal Feed Science and Technology 119(3-4): 323-331.

[6] Ammar, H., Lopez, S., Kammoun, M., Bodas, R., Firaldez, F. G., Gonsalez, J. S. (2009): Feeding quebracho tannins to sheep to enhances rumen fermentative activity to degrade browse shrubs. - Animal Feed Science and Technology 149: 1-15.

[7] AOAC (1990): Official Methods of Analysis. 15 $5^{\text {th }}$ ed. - Association of Official Analytical Chemists, Washington, DC.

[8] Ben Salem, H., Nefzaoui, A., Ben Salem, L. (2000): Supplementing range goats in central Tunisia with feed blocks or a mixture of Opuntia fius indica f. inermis and Atriplex nummularia L. Effects on behavioural activities and growth. - Proceedings of the 7th International Conference on Goats, Tours, France.

[9] Berrabah, S. and Chemissa, M. (2017): Aperçu ethnobotanique et chimique des Fabacées. - Mémoire de Master Académique en Gestion de l'Environnement. Universite Mohamed Boudiaf - M'sila, Algérie.

[10] Boubaker, A., Buldgen, A., Kayouli, C. (2004): Composition chimique et teneur en composés phénoliques des espèces arbustives du Nord-Ouest de la Tunisie. - Options méditérranéennes, série A, Séminaires Méditerranéens.

[11] Boughalleb, F., Mahmoudi, M., Abdellaoui, R., Yahia, B., Zaidi, S., Nasrin, N. (2019): Effect of long-term storage on phenolic composition, antioxidant capacity, and protein 
Mechergui et al.: Ecological diversity of spiny broom (Calicotome villosa (Poir.) Link) and sweet broom (Genista $\times$ spachiana) of three different provenances: chemical composition, secondary compounds of shrub leaves and responses to drought stress -3732 -

profiles of Calicotome villosa subsp. intermedia seeds. - Journal of Food Biochemistry e13093. 1-13.

[12] El-Keblawy, A. (2004): Salinity effects on seed germination of the common desert range grass, Panicum turgidum. - Seed Science and Technologie 32: 943-948.

[13] Elkhamlichi, A., El Antri, A., El Hajaji, H., El Bali, B., Oulyadi, H., Lachkar, M. (2017): Phytochemical constituents from the seeds of Calycotome villosa subsp. intermedia. Arabian Journal of Chemistry 10: S3580-S3583.

[14] Evans, C., Etherington, J. R. (1990): The effect of soil water potential on seed germination of some British plants. - New Phytologist 115: 539-48.

[15] Gamoun, M., Belgacem, A. O., Louhaichi, M. (2018): Diversity of desert rangelands of Tunisia. - Plant Diversity. DOI:10.1016/j.pld.2018.06.004.

[16] González-Andrés, F., Ortiz, J. M. (1996): Potential of Cytisus and allied genera (Genisteae: Fabaceae) as forage shrubs. - New Zealand Journal of Agricultural Research 39: 195-204.

[17] Gorai, M., Neffati, M. (2007): Germination responses of Reaumuria vermiculata to salinity and temperature. - Annals of Applied Biology 151: 53-59.

[18] Gorai, M., Tlig, T., Neffati, M. (2009): Influence of water stress on seed germination characteristics in invasive Diplotaxis harra (Forssk.) (Brassicaceae) in arid zone of Tunisia. - Journal of Phytology 1: 249-254.

[19] Gorai, M., Gasmi, H., Neffati, M. (2011): Factors influencing seed germination of medicinal plant Salvia aegyptiaca L. (Lamiaceae). - Saudi Journal of Biological Sciences 18: 255-260.

[20] He, X. Q., Du, C., Shao, Z., Li, Q. (2009): Effect of salt and water stress on seed germination of Dianthus chinensis L. Academic conference on horticulture. - Science Technology 12: 60-62.

[21] Huang, J., Reddman, R. E. (1995): Salt tolerance of Hordeum and Brassica species during germination and early growth. - Canadian Journal of Botany Science 75: 815-819.

[22] Huang, Z. Y., Zhang, X. S., Zheng, G. H., Gutterman, Y. (2003): Influence of light, temperature, salinity and storage on seed germination of Haloxylon ammodendron.Journal of Arid Environments 55: 453-464.

[23] Ibanez, A. N., Passera, C. B. (1997): Factors affecting the germination of albaida (Anthyllis cytisoides L.), a forage legume of the Mediterranean coast. - Journal of Arid Environments 35: 225-231.

[24] ISO (1997): Aliments des animaux. Détermination de la teneur en azote et calcul de la teneur en protéines brutes. Méthode Kjeldahl. - International Organization of Standardization, Geneva.

[25] Judd, W. S., Campbell, C. S., Kellogg, E. A., Stevens, P. (2002): Botanique systématique. Une perspective phyllogénétique. - Systematics and Geography of Plants 72(1): 242-243.

[26] Kaitho, R. J., Umunna, N. N., Nsahlai, I. V., Tamminga, S., Van Bruchem, J. (1998): Nitrogen in browse species: ruminal degradability and postruminal digestibility measured by mobile nylon bag and in vitro techniques. - Journal of Sciences Food and Agriculture 76: 488-498.

[27] Katembe, W. J., Ungar, I. A., Mitchell, J. P. (1998): Effect of salinity on germination and seedling growth of two Atriplex species. - Annals of Botany 82: 167-171.

[28] Katoch, R., Thakur, M., Kumar, N. (2012): Effect of morphological stage and clipping intervals on quality and digestibility of tall fescue (Festuca arundinacea Schreb.) and Setaria (Setaria anceps Stapf.). - Range Management and Agroforestry 33(2): 185-192.

[29] Khan, M. A., Ungar, I. A. (1996): Alleviation of seed dormancy in the desert forb Zygophyllum simplex L. from Pakistan. - Annals of Botany 80: 395-400.

[30] Khan, M. A., Gulzar, S. (2003): Germination responses of Sporobolus ioclados: a saline desert grass. - Journal of Arid Environments 53: 387-394.

[31] Khan, M. A., Gul, B., Weber, D. J. (2002): Seed germination in relation to salinity and temperature in Sarcobatus vermiculatus. - Biologia Plantarum 45: 133-135. 
Mechergui et al.: Ecological diversity of spiny broom (Calicotome villosa (Poir.) Link) and sweet broom (Genista $\times$ spachiana) of three different provenances: chemical composition, secondary compounds of shrub leaves and responses to drought stress - 3733 -

[32] Kumar, R., Vaithiyanathan, S. (1990): Occurrence nutritional significance and effect animal productivity of tannins in tree leaves. - Animal Feed Sciences and Technology 30: 21-38.

[33] Lachiheb, K., Neffati, M., Zid, E. (2004): Aptitudes germinatives de certaines graminées halophytes spontanées de la Tunisie méridionale. - Cahiers Options Méditerranéennes 62: 89-93.

[34] Lajnef, H. B., Mejri, H., Feriani, A., Khemiri, S., Saadaoui, E., Nasri, N., Tlili, N. (2015): Prosopis farcta seeds: potential source of protein and unsaturated fatty acids. - Journal of the American Oil Chemists' Society 92(7): 1043-1050.

[35] Liu, H. Y., Yu, X., Cui, D. Y., Sun, M. H., Sun, W. N., Tang, Z. C. (2007): The role of water channel proteins and nitric oxide signaling in rice seed germination. - Cell Research 17(7): 638-649.

[36] Makkar, H. P. S., Singh, B. (1991): Composition, tannin levels and in-sacco dry matter digestibility of fresh and fallen oak (Quercus incana) leaves. - Bioresource and Technologie 37: 185-187.

[37] Makkar, H. P. S., Bluemmel, M., Borowy, N. K., Becker, K. (1993): Gravimetric determination of tannins and their correlations with chemical and protein precipitation methods. - Journal Science of Food Agriculture 61: 161-165.

[38] Mandana, S., Thomas, B., Sven, A. (2017): Germination of Atriplex halimus seeds under Salinity and Water Stress. - Ecological Engineering 102: 636-640.

[39] Maraghni, M., Gorai, M., Neffati, M. (2010): Seed germination at different temperatures and water stress levels, and seedling emergence from different depths of Ziziphus lotus. South African Journal of Botany 76: 453-459.

[40] Mebirouk-Boudechiche, L., Boudechiche, L., Chemmam, M., Djaballah, S., Bouzouraa, I., Cherif, C. (2015): Une estimation de la biomasse foliaire fourragère de Pistacia lentiscus et Calycotome spinosa, arbustes des subéraies en Algérie. - Fourrages 221: 77 83.

[41] Mechergui, K., Jaouadi, W., Khouja, M. L. (2017): Pastoral plants for rehabilitation of degraded soil in Tunisia: the case for use of Calicotome villosa and Genista spachiana (Fabaceae). - Biologija 63(1): 23-32.

[42] Minson, D. (1990): Forage in Ruminant Nutrition. - Academic Press, Inc, New York.

[43] Mohamed, M. B., Keerthikaw, A., Gupta, D. K., Shukla, A. K., Jangid, B. L. (2018): Effect of seed morphometric variability on germination and seedling characteristics of Prosopis cineraria (1.) Druce under arid condition of Rajasthan. - Range Management and Agroforestry 39(1): 126-129.

[44] Mohan, S. V., Nikhil, G., Chiranjeevi, P., Reddy, C. N., Rohit, M., Kumar, A. N., Sarkar, O. (2016): Waste biorefinery models towards sustainable circular bioeconomy: critical review and future perspectives. - Bioresource Technology 215: 2-12.

[45] Muñoz-Rodríguez, A. F., Rodríguez-Rubio, P., Nieva, F. J., Fernández-Illescas, F., Sánchez-Gullon, E., Soto, J. M., Hermosos-López, V., Márquez-García, B. (2012): The Importance of Bracteoles in Ensuring Atriplex Halimus Germination under Optimal Conditions. - Fresenius Environmental Bulletin 21(11c): 3521-3526.

[46] Muñoz-Rodríguez, A. F., Sanjosé, I. B. Márquez-García, I., Infante-Izquierdo, M. D., Polo-Ávila, A., Nieva, F. J. J., Castillo, J. M. (2017): Germination syndromes in response to salinity of chenopodiaceae halophytes along the intertidal gradient. - Aquatic Botany 139: 48-56.

[47] Norton, B. W. (2003): The Nutritive Value of Tree Legumes. - CAB International, Wallingford.

[48] Pascual, J. J., Cervera, C., Fernandezcarmona, J. (2000): Comparison of different in vitro digestibility methods for nutritive evaluation of rabbit diets. - World Rabbit Science 8: 93-97.

[49] Pistelli, L., Fiumi, C., Morelli, I., Giachi, I. (2003): Flavonoids from Calicotome villosa. - Fitoterapia 74(4): 417-419. 
Mechergui et al.: Ecological diversity of spiny broom (Calicotome villosa (Poir.) Link) and sweet broom (Genista $\times$ spachiana) of three different provenances: chemical composition, secondary compounds of shrub leaves and responses to drought stress - 3734 -

[50] Porter, L. J., Hrstich, L. N., Chen, B. G. (1986): The conversion of procyanidins and prodelphinidins to cyaniding and delphinidin. - Phytochemistry 25: 223-230.

[51] Rathore, V. S., Singh, J. P., Roy, M. M. (2011): Shrubs of hot arid Rajasthan: economic and ecological imperatives. A review. - Range Management and Agroforestry 32(2): 7178.

[52] Redondo, S., Rubio-Casal, A. E., Castillo, J. M., Luque, C. J., Alvarez, A. A., Luque, T., Figueroa, M. E. (2004): Influences of salinity and light on germination of three Sarcocornia taxa with contrasted habitats. - Aquatic Botany 78(3): 255-264.

[53] Redondo-Gómez, S., Mateos-Naranjo, E., Davy, A. J., Fernández-Muñoz, F., Castellanos, E. M., Luque, T. (2007): Growth and photosynthetic responses to salinity of the saltmarsh shrub Atriplex portulacoides. - Annals of Botany 100: 555-563.

[54] Rira, M. (2006): Effet des polyphénols et des tanins sur l'activité métabolique du microbiote ruminal d'ovins. - Mémoire de Magister, Université Mentouri de Constantine, Algérie.

[55] Rybiński, W., Święcicki, W., Bocianowski, J., Börner, A., Starzycka-Korbas, E., Starzycki, M. (2018): Variability of fat content and fatty acids profiles in seeds of a Polish white lupin (Lupinus albus L.) collection. - Genetic Resources and Crop Evolution 65(2): 417-431.

[56] Selmi, H., Hasnaoui, M., Tibaoui, G., Askri, H., Bahri, A., Boussaidi, N., Alaoui, F., Rouissi, H. (2018): Fermentation ruminale et composition chimique de quelques arbustes du Nord de la Tunisie. - Journal of New Sciences Agriculture and Biotechnology CIRS (12): 3379-3385.

[57] Selmi, H., Dhifallah, A., Jedidi, S., Brahmi, N., Rouissi, H. (2020): In vitro ruminal fermentation, nutritional evaluation and antioxidant activity of some forest shrubs of North West Tunisia for Goats. - Moroccan Journal of Agricultural Sciences 1(1): 50-53.

[58] Sharma, M. L. (1976): Interaction of water potential and temperature effects on germination of three Semi-arid plant species. - Agronomy Journal 68: 390-394.

[59] Silva-Pando, F. J. M., Gonzalez Hernandez, P., Castro Garcia, P. (1999): Nutritional characteristics of some common woody plants in shrublands of Galicia (northwest Iberian peninsula). - Grassland Science of European 4: 121-125.

[60] Spear, J. W. (1994): Mineral in Forages. - In: Faher, J. R. (ed.) Forage Quality, Evaluation and Utilization. National Conference on Forage Quality, Lincoln.

[61] Tlig, T., Gorai, M., Neffati, M. (2008): Germination responses of Diplotaxis harra to temperature and salinity. - Flora 203: 421-428.

[62] Tlili, A., Zammouri, J., Gorai, M., Neffati, M. (2019): Ecological role of bracteoles in seed dispersal and germination of the North African halophyte Atriplex mollis under contrasting environments. - Botany Letters 166(4): 478-486.

[63] Tobe, K., Li, X. M., Omasa, K. (2000): Effects of sodium chloride on seed, germination and growth of two Chinese desert shrubs, Haloxylon ammodendron and Haloxylon persicum (Chenopodiaceae). - Australian Journal of Botany 48: 455-460.

[64] Troszynska, A., Ciska, E. (2002): Phenolic compounds of seed coats of white and coloured varieties of pea (Pisum sativum L.) and their total antioxidant activity. - Czech Journal of Food Sciences 20(1): 15-22.

[65] Ungar, I. A. (1995): Seed Germination and Seed-Bank Ecology of Halophytes. - In: Kigel, J., Galili, G. (eds.) Seed Development and Germination. Marcel Dekker, New York.

[66] Van Soest, P. J. (1994): Nutritional Ecology of the Ruminant. - Cornell University Press, Ithaca, NY.

[67] Van Soest, P. J., Robertson, J. B., Lewis, B. A. (1991): Methods for dietary fire, neutral detergent fire and non-starch polysaccharides in relation to animal nutrition. - Journal of Dairy Science 74: 3583-3597. 
[68] Welbaum, G. E., Tissaoui, T., Bradford, K. J. (1990): Water relations of seed germination in muskmelon (Cucumis melo L.) III. Sensitivity of germination to water potential and abscisic acid during development. - Plant Physiology 92: 1029-1037.

[69] William, J. K., Irwin, A. U., John, P. M. (1998): Effect of salinity on germination and seedling growth of two Atriplex species (Chenopodiaceae). - Annals of Botany 82(2): 167-175.

[70] Yan, C., Wei, Y. (2014): The effect of salinity on the germination of dimorphic seeds of Atriplex micrantha, an annual inhabiting Junggar Desert. - Vegetos 27(1): 207-212.

[71] Yousheng, C., Sziklai, O. (1985): Preliminary study on the germination of Toona sinensis (A. Juss.) roem. seed from eleven Chinese provenances. - Forest Ecology and Management 10(3): 269-281.

[72] Youssef, A. M. (2009): Seed germination of some desert plants from Egypt. - Journal of Applied Sciences Research 5(2): 144-150.

[73] Zimmer, N., Cordesse, R. (1996): Influence des tanins sur la valeur nutritive des aliments pour ruminants. INRA. - Revue de la Production Animale 9: 167-179. 